\title{
Modelling the complexity of pandemic-related lifestyle quality change and mental health: an analysis of a nationally representative UK general population sample
}

\author{
Sarah Butter ${ }^{1}$ (D) Jamie Murphy ${ }^{2} \cdot$ Philip Hyland $^{3}$. Orla McBride ${ }^{2} \cdot$ Mark Shevlin $^{2} \cdot$ Todd K. Hartman $^{4} \cdot$ Kate Bennett $^{5}$. \\ Jilly Gibson-Miller ${ }^{1} \cdot$ Liat Levita $^{1} \cdot$ Anton P. Martinez ${ }^{1} \cdot$ Liam Mason $^{6} \cdot$ Ryan McKay $^{7} \cdot$ Thomas V. A. Stocks $^{1}$. \\ Frédérique Vallières ${ }^{8} \cdot$ Richard $P$. Bentall $^{1}$
}

Received: 16 March 2021 / Accepted: 5 December 2021 / Published online: 16 December 2021

(c) The Author(s) 2021

\begin{abstract}
Purpose The COVID-19 pandemic has affected the way many individuals go about their daily lives. This study attempted to model the complexity of change in lifestyle quality as a result of the COVID-19 pandemic and its context within the UK adult population.

Methods Data from the COVID-19 Psychological Research Consortium Study (Wave 3, July 2020; $N=1166$ ) were utilised. A measure of COVID-19-related lifestyle change captured how individuals' lifestyle quality had been altered as a consequence of the pandemic. Exploratory factor analysis and latent profile analysis were used to identify distinct lifestyle quality change subgroups, while multinomial logistic regression analysis was employed to describe class membership.

Results Five lifestyle dimensions, reflecting partner relationships, health, family and friend relations, personal and social activities, and work life, were identified by the EFA, and seven classes characterised by distinct patterns of change across these dimensions emerged from the LPA: (1) better overall (3.3\%), (2) worse except partner relations (6.0\%), (3) worse overall (2.5\%), (4) better relationships (9.5\%), (5) better except partner relations (4.3\%), (6) no different (67.9\%), and (7) worse partner relations only (6.5\%). Predictor variables differentiated membership of classes. Notably, classes 3 and 7 were associated with poorer mental health (COVID-19 related PTSD and suicidal ideation).

Conclusions Four months into the pandemic, most individuals' lifestyle quality remained largely unaffected by the crisis. Concerningly however, a substantial minority (15\%) experienced worsened lifestyles compared to before the pandemic. In particular, a pronounced deterioration in partner relations seemed to constitute the more severe pandemic-related lifestyle change.
\end{abstract}

Keywords Lifestyle $\cdot$ COVID-19 $\cdot$ Pandemic $\cdot$ Mental health $\cdot$ Relationships $\cdot$ Latent variable modelling $\cdot$ UK

Sarah Butter

s.butter@sheffield.ac.uk

1 Department of Psychology, University of Sheffield, Cathedral Court, 1 Vicar Lane, Sheffield S1 2LT, England

2 School of Psychology, Ulster University, Coleraine, Northern Ireland

3 Department of Psychology, Maynooth University, Kildare, Ireland

4 Sheffield Methods Institute, University of Sheffield, Sheffield, England
5 Department of Psychology, University of Liverpool, Liverpool, England

6 Division of Psychology and Language Sciences, University College London, London, England

7 Department of Psychology, Royal Holloway, University of London, London, England

8 Trinity Centre for Global Health, Trinity College Dublin, Dublin, Ireland 


\section{Introduction}

The strict COVID-19-related restrictions and regulations (e.g. lockdowns, social distancing) that have been put in place have considerably changed many individuals' daily lives, routines, and relationships [1]. These measures have been effective in suppressing the transmission of the disease and will likely remain in place pending full rollout of vaccines that have been developed [2]. As a result, there has been widespread and ongoing concern that government-prescribed mitigation measures have, alongside virus-related morbidity, mortality and grief, negatively impacted the mental health of the general population [1, $3-5]$. A recent meta-analysis examining changes in mental health pre- and post-COVID-19 outbreak suggests that there has been a small overall increase in symptoms of anxiety and depression [6]. However, psychological responses since the outbreak appear to be highly heterogeneous [7, 8].

Specific COVID-19-related lifestyle changes have been documented in relation to health behaviours, including decreased physical activity, increased sedentary behaviour, screen time, food and alcohol consumption, unhealthier food choices, and poorer sleep [9-11]. Moreover, disruptions to personal relationships and social activity have been common [12-16]. Many individuals may also be under increased financial pressures as a result of unemployment or reduced working hours [17-19], while employed individuals may be struggling with changes to work schedules, roles and adjusting to a home-working environment [15, 20-22]. These negative lifestyle changes have been associated with poor mental health outcomes during this crisis in a number of studies [10, 22, 23]. Yet, it is underappreciated that individuals may also respond positively to the changes in life brought about by the COVID-19 pandemic. For example, some studies have identified groups of individuals who are living healthier lifestyles during the pandemic [9], reported improvements in their relationship satisfaction [16], and have decreased their overall spending $[19,24]$, all of which may positively impact their lives.

Importantly, however, these changes do not affect everyone equally. For example, unemployment and financial difficulties appear to be affecting the young, least educated, ethnic minorities, women and those with pre-existing financial difficulties the most $[17,19,25]$. Parents are negatively affected by school closures, particularly mothers who appear to be shouldering more caring responsibilities and are more likely to experience negative employment outcomes as a result of home-schooling demands [19, 26, 27]. Additionally, those living in cramped or poor housing conditions may also be more negatively affected [28].
Furthermore, particular lifestyle changes may be likely to co-occur with one another. For example, financial strain experienced by couples during the pandemic may negatively affect their relationship quality and satisfaction [29, 30].

To model and describe the complexity of pandemicrelated lifestyle quality change, as well as its context and potential consequences, the following study had three objectives. First, using a broad array of social, health, relationship and economic lifestyle indicators that were designed to capture pandemic-induced lifestyle changes, we sought to identify the primary dimensions of lifestyle quality change within the general adult population during the first 4 months of the COVID-19 pandemic. In doing so, we aimed to distil the complexity of these many and varied lifestyle changes into a more parsimonious representation of pandemic-related change in lifestyle quality. Second, we then sought to identify if there were distinct groups within the population who were characterised by the same profile of variation across the dimensions of lifestyle quality change. This afforded an opportunity to identify, not only, what aspects of lifestyle changed for distinct groups within the population, but whether the lifestyles of these groups were changing for better or worse. Third, we aimed to describe and differentiate the membership of the distinct lifestyle quality change groups using a variety of sociodemographic, COVID-19-related, psychological, and mental health variables to better understand whose lives were changing and potentially reveal some of the factors that may be underlying these changes.

\section{Method}

\section{Sample}

Launched in March 2020, the COVID-19 Psychological Research Consortium (C19PRC) Study is an online, longitudinal study which was designed to measure, assess, and monitor the population's psychological and social adjustment to the COVID-19 pandemic. Briefly, at baseline (referred to as C19PRC-UKW1; 23-28 March 2020), 2025 adults aged 18 years and older were recruited via the survey company Qualtrics. The current study utilised follow-up survey data collected from this cohort during 9-23 July 2020, Wave 3 of the study (C19PRC-UKW3; $N=1166 ; 57.6 \%$ retention rate), approximately 4 months after the first nationwide lockdown was imposed in the UK. During this point in the pandemic, the UK was at the tail end of its first wave of COVID-19 when the number of daily new confirmed positive COVID19 cases and daily death rate had declined considerably from peaks in mid-to-late April 2020 (see [31] for details).

Quota sampling methods were used at baseline to ensure the sample was representative of the UK adult population in 
terms of age, sex, and gross household income. Additionally, the baseline sample was broadly in line with populationlevel estimates in relation to economic activity, ethnicity, household composition and residency within the UK. Poststratification weights were applied to the Wave 3 sample to ensure it was as representative of the baseline as possible. Thus, the current sample mirrored the population distribution of the baseline sample regarding age, sex, income, ethnicity, urbanicity, household composition and being born or raised in the UK. Ethical approval for the study was granted by the University of Sheffield (Ref no. 033759). A detailed methodological account of the C19PRC-UK Study, including sampling and design, fieldwork procedures, quality control, sample representativeness, weighting and attrition at Wave 1-Wave 3 can be found elsewhere [31, 32].

\section{Measures}

\section{Pandemic-related lifestyle change}

A series of questions were generated for the Wave 3 study to assess changes to respondents' lifestyle quality as a result of the pandemic [31]. Respondents were presented with a list of 19 lifestyle indicators including relationship with intimate partner, work role, exercise, and religious/spiritual life, and asked to indicate whether their life was 'Better' (1), 'No different' (2) or 'Worse' (3) now than before the COVID-19 pandemic in relation to each indicator. Respondents were also presented with a 'Not applicable' response (e.g. nonreligious individuals could endorse this option for the item regarding changes in their 'religious/spiritual life'); for the purposes of the current study, this response was collapsed into the 'No different' category to indicate lack of change since the pandemic began. The 19 lifestyle indicators used in the study are presented in Table 1.

\section{Predictor variables}

A number of sociodemographic, COVID-19-related, psychological and mental health variables were used to predict patterns of pandemic-related lifestyle quality change. Full details of predictor variables are available in Online Resource 1.

Sociodemographic variables: age, gender (male, female), ethnicity (white British/Irish, ethnic minority), urbanicity (city, suburb/town/rural), current economic activity (active, inactive), gross household income (pre-pandemic, in 2019; $£ 0-£ 300$ per week, $£ 301-£ 490$ per week, $£ 491-£ 740$ per week, $£ 641-£ 1,111$ per week, $£ 1,112+$ per week), relationship status (in a relationship, not in a relationship), presence of dependent children in the home (yes, no), and number of bedrooms in the household ( $0 / 1$ through to $5+$ ). All sociodemographic variables were measured at Wave 3 (July 2020)

Table 1 Endorsement of pandemic-related lifestyle change ( $N=1166$, weighted data)

\begin{tabular}{|c|c|c|c|c|}
\hline \multirow{2}{*}{$\begin{array}{l}\text { Please indicate if the following areas of your life are better or worse } \\
\text { now than they were before the COVID-19 pandemic? }\end{array}$} & \multicolumn{4}{|l|}{$N(\%)$} \\
\hline & No different & Better & Worse & $\begin{array}{l}\text { Ratio } \\
\text { worse:better }\end{array}$ \\
\hline Home life & $791(67.8)$ & $200(17.2)$ & $175(15.0)$ & $0.9: 1$ \\
\hline Relationship with your intimate partner & $892(76.5)$ & $157(13.4)$ & $118(10.1)$ & $0.8: 1$ \\
\hline Relationship with your family & $873(74.9)$ & $183(15.7)$ & $110(9.5)$ & $0.6: 1$ \\
\hline Relationship with your children & $947(81.2)$ & $152(13.1)$ & $67(5.7)$ & $0.4: 1$ \\
\hline Relationship with your friends & $878(75.3)$ & $94(8.1)$ & $194(16.7)$ & $2.1: 1$ \\
\hline Diet & $664(57.0)$ & $181(15.5)$ & $321(27.5)$ & $1.8: 1$ \\
\hline Exercise & $538(46.1)$ & $280(24.0)$ & 349 (29.9) & $1.2: 1$ \\
\hline Taking care of your mental health & $773(66.3)$ & $115(9.8)$ & $278(23.9)$ & $2.4: 1$ \\
\hline Taking care of your physical health & $665(57.1)$ & $214(18.4)$ & $286(24.6)$ & $1.3: 1$ \\
\hline Work-life balance & $783(67.1 \%)$ & $214(18.3)$ & $170(14.5)$ & $0.8: 1$ \\
\hline Work role & $866(74.3)$ & $107(9.2)$ & $193(16.5)$ & $1.8: 1$ \\
\hline Relationship with your work colleagues & $951(81.6)$ & $92(7.9)$ & $123(10.6)$ & $1.3: 1$ \\
\hline Time spent commuting & $792(67.9)$ & $314(26.9)$ & $60(5.1)$ & $0.2: 1$ \\
\hline Education/personal development & $933(80.0)$ & $127(10.9)$ & $106(9.1)$ & $0.8: 1$ \\
\hline Socialising & $565(48.5)$ & $75(6.4)$ & $526(45.1)$ & $7: 1$ \\
\hline Sex life & $914(78.4)$ & $82(7.1)$ & $170(14.6)$ & $2.1: 1$ \\
\hline Engagement in hobbies and pastimes & $716(61.4)$ & $225(19.3)$ & $225(19.3)$ & $1: 1$ \\
\hline Religious or spiritual life & $1012(86.8)$ & $56(4.8)$ & $98(8.4)$ & $1.8: 1$ \\
\hline Social media use & $877(75.2)$ & $145(12.4)$ & 144 (12.4) & $1: 1$ \\
\hline
\end{tabular}


with the exception of urbanicity, ethnicity and gross household income (measured at Wave 1; March 2020).

COVID-19-related variables: respondents were also asked whether they were a government-defined keyworker (yes, no), living in an area under local lockdown at the time of the study (yes, no), whether their monthly household income had changed since before the pandemic (lost income, no lost income), and whether they had a chronic health condition (self and close family members; yes, no), as well as about their degree of COVID-19 related anxiety (low, medium, high), perceived COVID-19 infection status (self and family members; infected, not infected), and if someone close to them had died from COVID-19 (yes, no). All COVID-19-related variables were measured at Wave 3 with the exception of self and family member health conditions, which were measured at Wave 1.

Psychological related variables: several psychological variables measured at Wave 3 were included: loneliness was measured by the three-item Loneliness Scale [33], happiness with the Subjective Happiness Scale [34], hopefulness with the Brief-H-Pos Scale [35] and social support with the Modified Medical Outcome Social Support Survey (mMOSSSS) [36]. Additional psychological scales, measured at Wave 1 were also included: resilience was measured using the Brief Resilience Scale [37], death anxiety with Death Anxiety Inventory [38], and intolerance of uncertainty with Intolerance of Uncertainty scale [39].

Mental health variables: several variables measured at Wave 3 were included as predictor variables. Depression was measured using the Patient Health Questionnaire-9 (PHQ9) [40], generalised anxiety with the Generalized Anxiety Disorder 7-item Scale (GAD-7) [41], and COVID-19-related posttraumatic stress with a modified version of the International Trauma Questionnaire (ITQ) [42]. Additionally, suicidal ideation since the outbreak of the pandemic was also measured in the sample.

\section{Analytic plan}

To address objectives 1 and 2, latent variable modelling was conducted in two stages. First, exploratory factor analysis (EFA; maximum likelihood extraction, oblique rotation) was employed to determine the latent structure of change in lifestyle quality during the pandemic based on responses to the 19 items measuring lifestyle change. The number of factors to be extracted was determined using eigenvalues as well as the interpretability and meaningfulness of the solution. Second, after establishing the appropriate number of dimensions of lifestyle quality change using EFA, latent profile analysis (LPA) was used to identify homogeneous groups, or classes, based on scores of these dimensions of lifestyle quality change. The fit of seven models (a two-class through an eight-class model) was assessed using LPA, with the factor scores generated from the EFA as continuous indicators.

The relative fit of the LPA models was compared by using three information theory-based fit statistics: the Akaike information criterion (AIC) [43], the Bayesian information criterion (BIC) [44] and the sample size-adjusted Bayesian information criterion (ssa-BIC) [45]. The model that produced the lowest values was judged to be the best-fitting model. However, the BIC is considered to be the best of the fit indices for deciding the number of classes in LPA [46]. The Lo-Mendell-Rubin likelihood ratio test (LRT) [47] can also be used to determine class enumeration. When the LRT becomes non-significant, it suggests the model with one less class is a better fit to the data. In addition to the fit statistics, it is important to consider the conceptual relevance of the latent profiles when interpreting the results. Robust maximum likelihood estimation [48] was used for the LPAs. To avoid solutions based on local maxima, 100 random sets of starting values were initially used, with 10 final stage optimisations.

To address objective 3, multinomial logistic regression was carried out to assess whether sociodemographic, COVID-19-specific, psychological and mental health variables could discriminate between class membership of the best fitting LPA. Analyses were conducted using SPSS v26 and Mplus version 7 [49]. Weighting procedures (see 'Sample') were applied when conducting the descriptive, EFA, and regression analyses.

\section{Results}

Endorsement frequencies for the 19 lifestyle quality indicators are reported in Table 1. More than half of respondents (57.0-86.8\%) indicated 'no difference' in each area of their life compared to before the pandemic, with the exception of 'Exercise' and 'Socialising'. In relation to 'Exercise', a quarter of individuals (24.0\%) indicated that this had improved, while three in ten reported that it had deteriorated. Additionally, almost half of the sample (45.1\%) indicated that their 'Socialising' was worse now than before the pandemic, whereas only around 1 in $15(6.4 \%)$ reported that it had improved. Other than 'Socialising', variables which had the largest worse:better ratios included 'taking care of your mental health' (2.4:1), 'relationship with your friends' (2.1:1), and 'sex life' (2.1:1), while 'relationship with your children' (0.4:1) and 'time spent commuting' (0.2:1) had the smallest worse:better ratios.

\section{Exploratory factor analysis}

Data suitability was assessed prior to conducting EFA. These results suggested that singularity was not a problem 
(determinant $=0.010$ ), and that the sample and correlation matrix were factorable $(\mathrm{KMO}=0.84$; Bartlett's Test of Sphericity: $\left.\chi^{2}=5348.27, \mathrm{df}=171, p<0.001\right)$. Correlations ranged between 0.06 and 0.68 (see Online Resource 1). Six dimensions were initially extracted with eigenvalues greater than one; however, the scree plot suggested that five or six dimensions might be retained. Further inspection of the six-factor solution revealed that it contained a dimension on which only one item loaded above 0.30 ; therefore, this model was dismissed as a viable solution. Further inspection of the five-factor solution revealed dimensions which were conceptually distinguishable. The results of maximum likelihood extraction with oblique (direct oblimin) rotation of this solution are presented in Table 2.

Three items loaded onto factor 1: relationship with intimate partner, home life, and sex life. This was labelled as the 'Partner relationship' dimension. Four items loaded onto factor 2 (taking care of your physical health, exercise, diet and taking care of your mental health), clearly reflecting a
'Healthy lifestyle' dimension. Four items loaded onto factor 3: work role, work-life balance, relationship with your work colleagues and time spent commuting. This was considered to reflect a 'Work life' dimension. Factor 4 contained three items, relationships with your family, children, and friends; this dimension was labelled 'Family and friends'. Finally, five items loaded onto factor 5: education/personal development, religious/spiritual life, engagement in hobbies and pastimes, social media use and socialising. This factor was labelled as the 'Personal and social activities' dimension. All items loaded positively onto their respective dimensions, indicating that higher scores related to worsening of that aspect of lifestyle. The strongest factor correlations were between 'Personal and social activities' and 'Work life' $(r=0.55)$ and between 'Partner relationship' and 'Family and friends' $(r=0.41)$.

Three indicators had low factor loadings $(<0.30)$. These were 'Relationship with your friends' $(0.257)$, 'Time spent commuting' (0.246) and 'Socialising'
Table 2 Factor analysis of lifestyle items $(N=1166$, weighted data)

\begin{tabular}{|c|c|c|c|c|c|}
\hline \multirow[t]{2}{*}{ Lifestyle items } & \multicolumn{5}{|l|}{ Factor } \\
\hline & 1 & 2 & 3 & 4 & 5 \\
\hline Home life & 0.369 & 0.098 & 0.195 & 0.228 & 0.004 \\
\hline Relationship with your intimate partner & 1.025 & -0.020 & -0.002 & 0.013 & -0.077 \\
\hline Relationship with your family & -0.020 & 0.006 & -0.011 & 0.786 & 0.000 \\
\hline Relationship with your children & 0.097 & -0.002 & -0.011 & $\mathbf{0 . 5 0 0}$ & -0.008 \\
\hline Relationship with your friends & -0.065 & 0.057 & 0.131 & 0.257 & 0.200 \\
\hline Diet & -0.014 & 0.544 & 0.087 & -0.004 & -0.009 \\
\hline Exercise & 0.025 & 0.812 & -0.096 & 0.010 & -0.034 \\
\hline Taking care of your mental health & 0.108 & 0.397 & 0.124 & -0.069 & 0.203 \\
\hline Taking care of your physical health & -0.018 & 0.862 & -0.006 & 0.052 & -0.014 \\
\hline Work-life balance & 0.015 & 0.059 & 0.566 & 0.052 & 0.042 \\
\hline Work role & -0.003 & 0.035 & 0.828 & 0.006 & -0.130 \\
\hline Relationship with your work colleagues & 0.043 & -0.016 & 0.480 & -0.037 & 0.144 \\
\hline Time spent commuting & 0.056 & -0.036 & 0.246 & 0.036 & 0.190 \\
\hline Education/personal development & 0.078 & -0.035 & 0.086 & -0.088 & 0.664 \\
\hline Socialising & -0.011 & 0.133 & 0.086 & -0.037 & 0.275 \\
\hline Sex life & 0.350 & 0.057 & -0.007 & 0.048 & 0.223 \\
\hline Engagement in hobbies and pastimes & 0.040 & 0.095 & -0.046 & 0.115 & 0.503 \\
\hline Religious or spiritual life & 0.014 & 0.039 & -0.054 & 0.041 & 0.528 \\
\hline Social media use & -0.010 & -0.045 & 0.049 & 0.048 & 0.320 \\
\hline Eigenvalue & 4.909 & 1.654 & 1.471 & 1.185 & 1.046 \\
\hline$\%$ Variance explained & $25.84 \%$ & $8.71 \%$ & $7.74 \%$ & $6.24 \%$ & $5.51 \%$ \\
\hline \multicolumn{6}{|l|}{ Factor correlations } \\
\hline F1: partner relationship & - & & & & \\
\hline F2: healthy lifestyle & 0.285 & - & & & \\
\hline F3: work life & 0.312 & 0.362 & - & & \\
\hline F4: family and friends & 0.407 & 0.260 & 0.251 & - & \\
\hline F5: personal and social activities & 0.359 & 0.369 & 0.553 & 0.371 & - \\
\hline
\end{tabular}

Strongest loading for each item in bold. Extraction: maximum likelihood; rotation: oblimin. Total variance explained: $54.03 \%$ 
(0.275). The current study sought to examine the dimensionality of lifestyle change during the pandemic, rather than test a theoretical model of lifestyle change. Therefore, these items were included in the model despite their low factor loadings. This decision was also as a result of the conceptual relevance of each of these items within their respective factors, and the large sample size used in the study [50].

\section{LPA on factor scores}

Fit indices for the LPAs are shown in Table 3. Class enumeration was based on both statistical and conceptual considerations. The AIC, BIC and ssaBIC continued to decrease from the two-class model through to the eight-class model. The LRT, however, became non-significant in the eightclass model. This result, combined with the decreasing BIC throughout the models, suggested that the seven-class model should be accepted. Inspection of the seven-class structure
Table 3 Fit statistics for latent profile analysis of weighted factor scores $(N=1166)$
Fig. 1 Seven-class latent profile analysis plot modelled using weighted factor scores from five-factor EFA solution. Higher scores indicate worsening on that lifestyle dimension

\begin{tabular}{|c|c|c|c|c|c|c|}
\hline Classes & Log-likelihood & AIC & BIC & ssaBIC & Entropy & LRT, $p$ \\
\hline 2 & -6950.107 & $13,932.213$ & $14,013.195$ & $13,962.373$ & 0.959 & $\begin{array}{l}865.300 \\
p<0.001\end{array}$ \\
\hline 3 & -4707.852 & 9459.705 & 9571.054 & 9501.175 & 1.000 & $\begin{array}{l}4381.104, \\
p<0.001\end{array}$ \\
\hline 4 & -4443.349 & 8942.698 & 9084.415 & 8995.477 & 0.994 & $\begin{array}{l}516.809 \\
p<0.001\end{array}$ \\
\hline 5 & -4162.936 & 8393.871 & 8565.957 & 8457.961 & 0.971 & $\begin{array}{l}547.894 \\
p<0.01\end{array}$ \\
\hline 6 & -3902.069 & 7884.137 & 8086.591 & 7959.537 & 0.974 & $\begin{array}{l}509.705 \\
p<0.01\end{array}$ \\
\hline 7 & -3609.170 & 7310.339 & 7543.161 & 7397.049 & 0.978 & $\begin{array}{l}572.290 \\
p<0.05\end{array}$ \\
\hline 8 & -3485.410 & 7074.820 & 7338.009 & 7172.839 & 0.976 & $\begin{array}{l}241.812 \\
p>0.05\end{array}$ \\
\hline
\end{tabular}

Selected model in bold

AIC Akaike information criterion, BIC Bayesian information criterion, ssaBIC sample size-adjusted BIC, LRT Lo-Mendell-Rubin adjusted likelihood ratio test

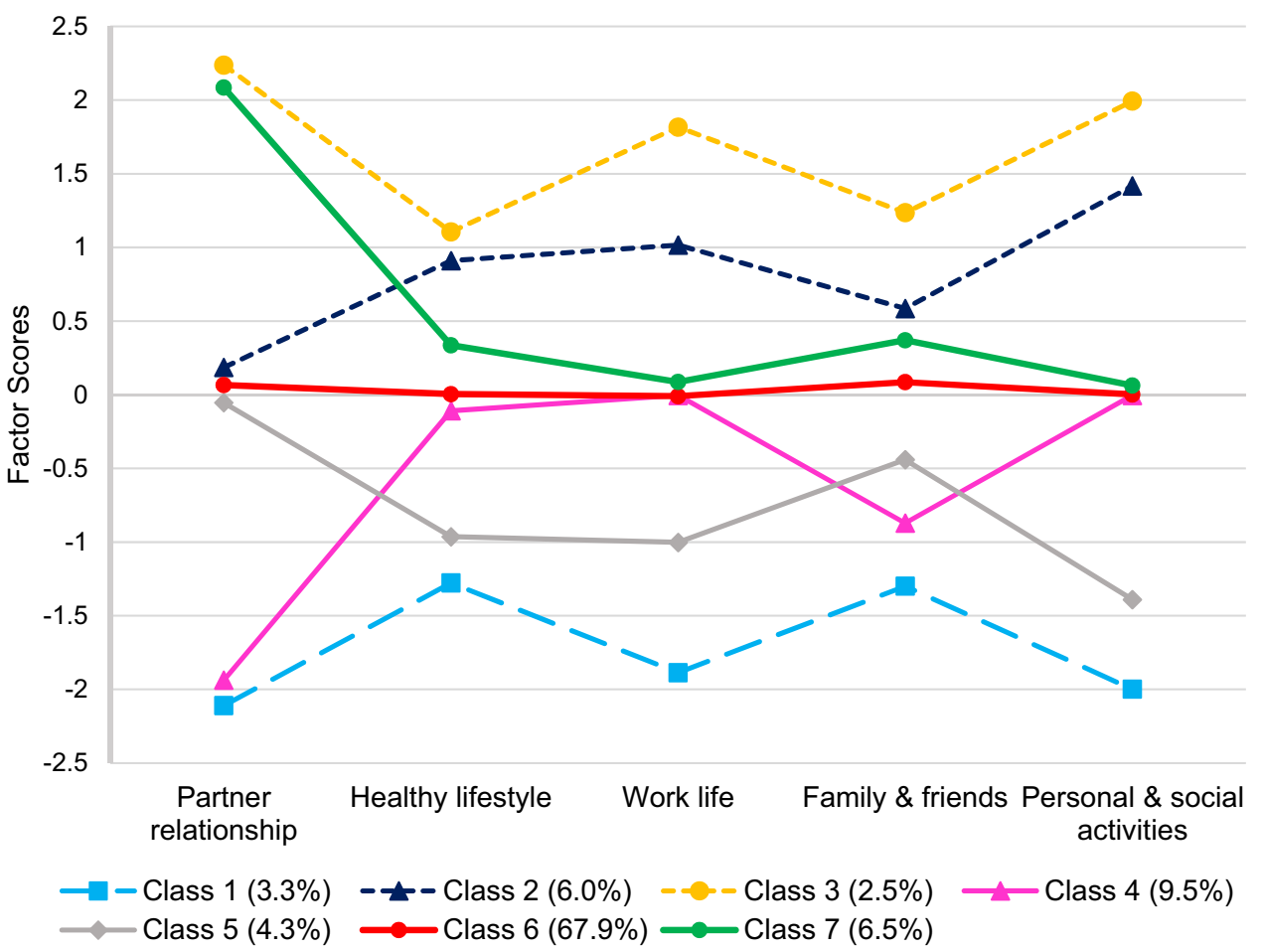


revealed the presence of distinct classes, with each class capturing a unique pattern of change or stability in lifestyle quality across the five dimensions (Fig. 1). Additionally, this solution indicated acceptable classification of participants (entropy $=0.98)$.

Class 1 (Better overall lifestyle; $n=38,3.3 \%$ ) comprised a group of adults whose factor scores indicated improvement across all dimensions (i.e. below 0 across all factors). Class 2 (Worse except partner; $n=70,6.0 \%$ ) consisted of a group whose profile indicated no difference on partner relations, but lifestyle deterioration across all other dimensions. Similarly, Class 3 (Worse overall lifestyle; $n=29$, $2.5 \%$ ), was the smallest class and represented a group of adults whose factor scores indicated worsening across all lifestyle dimensions, including partner relations. Class 4 (Better relationships; $n=111,9.5 \%$ ) comprised a group of adults with improvements mainly to their partner relationship/home life, as well as their relationships with family and friends, but with no difference on the remaining dimensions. Class 5 (Better except partner; $n=50,4.3 \%$ ), was similar in profile to Class 1 , with the exception that these individuals reported no difference to their partner relationships. Class 6 (No different; $n=792,67.9 \%$ ), was the largest subgroup, and comprised adults who reported relatively little change in their lifestyle since before the pandemic. Finally, Class 7 (Worse partner only; $n=76,6.5 \%$ ), consisted of a group who reported little difference to their lifestyle in relation to their engagement in healthy behaviours, work life, family/friend relationships and personal and social activities; however, their partner relationship greatly deteriorated.

\section{Predicting class membership}

Odds ratios (ORs) for the sociodemographic, COVID-19-related, mental health and psychological variables predicting class membership are shown in Table 4. Class 6 'No different' was used as the reference class. Having a better overall lifestyle now than before the pandemic (Class 1), was associated with being economically active $(\mathrm{OR}=3.90)$, being in a relationship $(\mathrm{OR}=2.95)$, living in a larger house (5 bedrooms compared to 3 bedrooms; $\mathrm{OR}=7.14$ ), and having higher levels of hopefulness $(\mathrm{OR}=1.55)$ and death anxiety $(\mathrm{OR}=1.05)$. The worse lifestyle except partner relationships class (Class 2) were more likely to be economically active $(\mathrm{OR}=2.36)$ and have higher levels of loneliness $(\mathrm{OR}=1.22)$. Having a worse overall lifestyle (Class 3 ) was associated with living in a city $(\mathrm{OR}=3.57)$, being of white British/Irish ethnicity $(\mathrm{OR}=7.46)$, being in a relationship $(\mathrm{OR}=7.99)$, being less likely to have a health condition $(\mathrm{OR}=8.33)$, being more likely to be a keyworker $(\mathrm{OR}=4.76)$, living in a local lockdown $(\mathrm{OR}=4.86)$, having higher levels of death anxiety $(\mathrm{OR}=1.07)$, meeting the criteria for COVID-19
PTSD $(\mathrm{OR}=5.88)$ and reporting suicidal ideation since the beginning of the pandemic $(\mathrm{OR}=4.24)$.

The better relationships class (Class 4 ) were more likely to have had a 2019 household income of $£ 1112+$ per week $(\mathrm{OR}=3.17)$ and $£ 301-£ 490$ per week $(\mathrm{OR}=3.17)$, were more likely to be in a relationship $(\mathrm{OR}=4.75)$, and were less likely to have a family member with a chronic health condition $(\mathrm{OR}=2.08)$ and to live in a local lockdown area $(\mathrm{OR}=11.11)$. These individuals also had greater levels of happiness $(\mathrm{OR}=1.43)$ and social support $(\mathrm{OR}=1.03)$. A better lifestyle with the exception of partner relationships (Class 5) was associated with being younger $(\mathrm{OR}=0.97)$, being economically active $(\mathrm{OR}=3.26)$, not being in a relationship ( $\mathrm{OR}=4.17)$, having lost income as a result of the pandemic $(\mathrm{OR}=1.99)$, not being a keyworker $(\mathrm{OR}=2.38)$ and having higher levels of hopefulness $(\mathrm{OR}=1.27)$. Finally, worse partner relationship only (Class 7) was associated with having a 2019 income of $£ 741-£ 1,111(\mathrm{OR}=3.18)$ and $£ 491-£ 740$ (OR $=3.84)$, being in a relationship $(\mathrm{OR}=5.48)$, having dependent children in the home $(\mathrm{OR}=2.75)$, having lost income as a result of the pandemic $(\mathrm{OR}=2.06)$, living in a smaller home ( 2 bedroom compared to 5 bedroom; $\mathrm{OR}=13.79)$, living in a local lockdown $(\mathrm{OR}=3.19)$, having a family member with a health condition $(\mathrm{OR}=2.18)$, having higher levels of loneliness ( $\mathrm{OR}=1.49)$, meeting the criteria for COVID-19 PTSD (OR =2.20) and reporting suicidal ideation since the beginning of the pandemic $(\mathrm{OR}=3.26)$.

\section{Discussion}

The seven classes identified in the current analyses revealed a number of interesting things about the lifestyle of the UK adult population 4 months after the first nationwide lockdown. These can be summarised as three key findings. First, the largest class, which comprised over two-thirds of the sample, reported virtually no change across the five lifestyle dimensions. The size of this class suggests that over the first 4 months of the pandemic, the quality of most individuals' lifestyles remained largely unchanged compared to their pre-pandemic lives. Second, nearly one-in-six individuals in the sample reported that they had experienced improvements in two or more areas of their lifestyle compared to before the pandemic (Classes 1, 4 and 5). Overall lifestyle improvement, improvement in partner and family and friend relations only, and better lifestyle with the exception of partner relationship, were generally characterised by a unique pattern of sociodemographic, COVID-19 and psychological associations. Moreover, none of these classes were associated with any of the four mental health covariates. Third, Classes 2, 3, and 7 comprised nearly one-in-seven individuals in the sample, and represented those members of the 
Table 4 Multinomial logistic regression predicting class membership (odds ratios) $(N=1049$, weighted data)

\begin{tabular}{|c|c|c|c|c|c|c|c|}
\hline & \multirow{2}{*}{$\begin{array}{l}N(\%) / \text { means } \\
\text { (range) }\end{array}$} & \multicolumn{6}{|l|}{ OR $(95 \% \mathrm{CI})$} \\
\hline & & $\begin{array}{l}\text { Class } 1(3.3 \%) \\
\text { Better overall }\end{array}$ & $\begin{array}{l}\text { Class } 2(6.0 \%) \\
\text { Worse except } \\
\text { partner }\end{array}$ & $\begin{array}{l}\text { Class } 3(2.5 \%) \\
\text { Worse overall }\end{array}$ & $\begin{array}{l}\text { Class } 4(9.5 \%) \\
\text { Better relation- } \\
\text { ships }\end{array}$ & $\begin{array}{l}\text { Class } 5(4.3 \%) \\
\text { Better except } \\
\text { partner }\end{array}$ & $\begin{array}{l}\text { Class } 7(6.5 \%) \\
\text { Worse partner } \\
\text { only }\end{array}$ \\
\hline Age & $45.80(18-87)$ & $\begin{array}{l}0.98(0.95- \\
1.01)\end{array}$ & $\begin{array}{l}0.99(0.97- \\
1.02)\end{array}$ & $\begin{array}{l}0.99(0.94- \\
1.04)\end{array}$ & $\begin{array}{l}0.99(0.97- \\
1.01)\end{array}$ & $\begin{array}{c}0.97(0.94- \\
0.99) * *\end{array}$ & $1.01(0.98-1.03)$ \\
\hline \multicolumn{8}{|l|}{ Gender } \\
\hline Male & $565(48.6)$ & $\begin{array}{l}0.54(0.24- \\
1.23)\end{array}$ & $\begin{array}{l}1.19(0.65- \\
2.18)\end{array}$ & $\begin{array}{l}1.87(0.59- \\
5.91)\end{array}$ & $\begin{array}{l}0.84(0.52- \\
1.36)\end{array}$ & $\begin{array}{l}0.92(0.46- \\
1.84)\end{array}$ & $0.62(0.33-1.18)$ \\
\hline Female & $598(51.4)$ & - & - & - & - & - & - \\
\hline \multicolumn{8}{|l|}{ Urbanicity } \\
\hline $\begin{array}{l}\text { Suburb/town/ } \\
\text { rural }\end{array}$ & $879(75.4)$ & $\begin{array}{l}0.61(0.27- \\
1.41)\end{array}$ & $\begin{array}{l}1.28(0.62- \\
2.68)\end{array}$ & $\begin{array}{l}0.28(0.08- \\
0.95) *\end{array}$ & $\begin{array}{l}0.77(0.44- \\
1.35)\end{array}$ & $\begin{array}{l}1.62(0.73- \\
3.59)\end{array}$ & $1.90(0.83-4.32)$ \\
\hline City & $287(24.6)$ & - & - & - & - & - & - \\
\hline \multicolumn{8}{|l|}{ Economic activity } \\
\hline $\begin{array}{l}\text { Economically } \\
\text { active }\end{array}$ & $765(65.6)$ & $\begin{array}{l}3.90(1.20- \\
12.63)^{*}\end{array}$ & $\begin{array}{l}2.36(1.10- \\
5.05)^{*}\end{array}$ & $\begin{array}{l}1.13(0.18- \\
7.11)\end{array}$ & $\begin{array}{l}1.20(0.64- \\
2.24)\end{array}$ & $\begin{array}{c}3.26(1.34- \\
7.95) * *\end{array}$ & $0.88(0.38-2.04)$ \\
\hline $\begin{array}{l}\text { Not economi- } \\
\text { cally active }\end{array}$ & $401(34.4)$ & - & - & - & - & - & - \\
\hline \multicolumn{8}{|c|}{ Gross income 2019} \\
\hline $\begin{array}{l}£ 1,112 \text { or } \\
\text { more per } \\
\text { week }\end{array}$ & $236(20.2)$ & $\begin{array}{l}0.41(0.08- \\
2.17)\end{array}$ & $\begin{array}{l}1.90(0.63- \\
5.72)\end{array}$ & $\begin{array}{l}0.99(0.11- \\
8.65)\end{array}$ & $\begin{array}{l}3.17(1.12- \\
8.98) *\end{array}$ & $\begin{array}{l}1.36(0.44- \\
4.23)\end{array}$ & $2.42(0.69-8.41)$ \\
\hline $\begin{array}{c}£ 741-£ 1,111 \\
\text { per week }\end{array}$ & $236(20.2)$ & $\begin{array}{l}0.71(0.16- \\
3.22)\end{array}$ & $\begin{array}{l}0.68(0.21- \\
2.26)\end{array}$ & $\begin{array}{l}0.37(0.04- \\
3.42)\end{array}$ & $\begin{array}{l}2.07(0.73- \\
5.87)\end{array}$ & $\begin{array}{l}1.27(0.41- \\
3.96)\end{array}$ & $3.18(1.01-9.99) *$ \\
\hline $\begin{array}{l}£ 491-£ 740 \text { per } \\
\text { week }\end{array}$ & $222(19.0)$ & $\begin{array}{l}1.92(0.50- \\
7.44)\end{array}$ & $\begin{array}{l}1.11(0.39- \\
3.13)\end{array}$ & $\begin{array}{l}1.01(0.14- \\
7.14)\end{array}$ & $\begin{array}{l}2.16(0.76- \\
\quad 6.15)\end{array}$ & $\begin{array}{l}0.84(0.29- \\
2.44)\end{array}$ & $\begin{array}{l}3.84(1.36- \\
10.81)^{*}\end{array}$ \\
\hline $\begin{array}{l}£ 301-£ 490 \text { per } \\
\text { week }\end{array}$ & $236(20.2)$ & $\begin{array}{l}1.78(0.45- \\
6.95)\end{array}$ & $\begin{array}{l}1.40(0.57- \\
3.44)\end{array}$ & $\begin{array}{l}0.60(0.08- \\
4.26)\end{array}$ & $\begin{array}{l}3.17(1.18- \\
8.53) *\end{array}$ & $\begin{array}{l}0.41(0.13- \\
1.31)\end{array}$ & $1.17(0.39-3.51)$ \\
\hline $\begin{array}{l}£ 0-£ 300 \text { per } \\
\text { week }\end{array}$ & $236(20.2)$ & - & - & - & - & - & - \\
\hline \multicolumn{8}{|l|}{ Ethnicity } \\
\hline $\begin{array}{l}\text { White British/ } \\
\text { Irish }\end{array}$ & $1018(87.3)$ & $\begin{array}{l}1.08(0.36- \\
3.24)\end{array}$ & $\begin{array}{l}2.25(0.74- \\
6.85)\end{array}$ & $\begin{array}{c}7.46(1.00- \\
55.84)^{*}\end{array}$ & $\begin{array}{l}0.74(0.36- \\
1.52)\end{array}$ & $\begin{array}{l}0.43(0.18- \\
1.01)\end{array}$ & $0.81(0.35-1.87)$ \\
\hline $\begin{array}{l}\text { Ethnic minor- } \\
\text { ity }\end{array}$ & $148(12.7)$ & - & - & - & - & - & - \\
\hline \multicolumn{8}{|l|}{ In a relationship } \\
\hline Yes & $716(61.4)$ & $\begin{array}{l}2.95(1.17- \\
7.42)^{*}\end{array}$ & $\begin{array}{l}1.08(0.53- \\
2.21)\end{array}$ & $\begin{array}{c}7.99(1.96- \\
32.62)^{* *}\end{array}$ & $\begin{array}{c}4.75(2.30- \\
9.84) * * *\end{array}$ & $\begin{array}{c}0.24(0.11- \\
0.55) * * *\end{array}$ & $\begin{array}{r}5.48(2.44- \\
12.31)^{* * * *}\end{array}$ \\
\hline No & $450(38.6)$ & - & - & - & - & - & - \\
\hline \multicolumn{8}{|c|}{ Children in the home } \\
\hline Yes & $328(28.1)$ & $\begin{array}{l}0.87(0.35- \\
2.19)\end{array}$ & $\begin{array}{l}0.74(0.34- \\
1.58)\end{array}$ & $\begin{array}{l}2.36(0.66- \\
8.39)\end{array}$ & $\begin{array}{l}1.45(0.85- \\
2.48)\end{array}$ & $\begin{array}{l}1.20(0.58- \\
2.50)\end{array}$ & $\begin{array}{c}2.75(1.39- \\
5.45) * *\end{array}$ \\
\hline No & $838(71.9)$ & - & - & - & - & - & - \\
\hline \multicolumn{8}{|c|}{ No. of bedrooms in the home } \\
\hline $\begin{array}{l}\text { Bedrooms: } \\
\text { none/1 }\end{array}$ & $126(10.8)$ & $\begin{array}{l}0.34(0.07- \\
1.79)\end{array}$ & $\begin{array}{l}1.61(0.30- \\
8.67)\end{array}$ & $\begin{array}{l}0.54(0.04- \\
7.68)\end{array}$ & $\begin{array}{l}3.32(0.92- \\
11.93)\end{array}$ & $\begin{array}{l}0.21(0.04- \\
1.13)\end{array}$ & $3.83(0.21-70.17)$ \\
\hline 2 & $254(21.8)$ & $\begin{array}{l}0.40(0.09- \\
1.79)\end{array}$ & $\begin{array}{l}0.78(0.16- \\
3.85)\end{array}$ & $\begin{array}{l}0.14(0.01- \\
1.66)\end{array}$ & $\begin{array}{l}1.78(0.58- \\
5.50)\end{array}$ & $\begin{array}{l}0.50(0.13- \\
1.86)\end{array}$ & $\begin{array}{c}13.79(1.03- \\
184.95)^{*}\end{array}$ \\
\hline 3 & $486(41.7)$ & $\begin{array}{c}0.14(0.03- \\
0.63)^{* *}\end{array}$ & $\begin{array}{l}0.96(0.22- \\
4.23)\end{array}$ & $\begin{array}{l}0.13(0.01- \\
1.17)\end{array}$ & $\begin{array}{l}1.34(0.48- \\
3.77)\end{array}$ & $\begin{array}{l}0.46(0.14- \\
1.54)\end{array}$ & $5.37(0.42-68.31)$ \\
\hline 4 & $232(19.9)$ & $\begin{array}{l}1.04(0.25- \\
4.25)\end{array}$ & $\begin{array}{l}0.93(0.20- \\
4.40)\end{array}$ & $\begin{array}{l}0.16(0.01- \\
1.77)\end{array}$ & $\begin{array}{l}1.44(0.50- \\
4.17)\end{array}$ & $\begin{array}{l}0.45(0.12- \\
1.63)\end{array}$ & $6.08(0.47-78.92)$ \\
\hline 5 & $68(5.8)$ & - & - & - & - & - & - \\
\hline
\end{tabular}


Table 4 (continued)

\begin{tabular}{|c|c|c|c|c|c|c|c|}
\hline & \multirow{2}{*}{$\begin{array}{l}N(\%) / \text { means } \\
\text { (range) }\end{array}$} & \multicolumn{6}{|l|}{ OR $(95 \% \mathrm{CI})$} \\
\hline & & $\begin{array}{l}\text { Class } 1(3.3 \%) \\
\text { Better overall }\end{array}$ & $\begin{array}{l}\text { Class } 2(6.0 \%) \\
\text { Worse except } \\
\text { partner }\end{array}$ & $\begin{array}{l}\text { Class } 3(2.5 \%) \\
\text { Worse overall }\end{array}$ & $\begin{array}{l}\text { Class } 4(9.5 \%) \\
\text { Better relation- } \\
\text { ships }\end{array}$ & $\begin{array}{l}\text { Class } 5(4.3 \%) \\
\text { Better except } \\
\text { partner }\end{array}$ & $\begin{array}{l}\text { Class } 7(6.5 \%) \\
\text { Worse partner } \\
\text { only }\end{array}$ \\
\hline \multicolumn{8}{|c|}{ C19-related lost income } \\
\hline Yes & $377(32.4)$ & $\begin{array}{l}0.78(0.33- \\
1.85)\end{array}$ & $\begin{array}{l}1.78(0.97- \\
3.28)\end{array}$ & $\begin{array}{l}1.53(0.47- \\
4.94)\end{array}$ & $\begin{array}{l}1.22(0.75- \\
1.98)\end{array}$ & $\begin{array}{l}1.99(1.04- \\
3.80)^{*}\end{array}$ & $2.06(1.10-3.84) *$ \\
\hline No & $789(67.6)$ & - & - & - & - & - & - \\
\hline \multicolumn{8}{|c|}{ Health condition-self } \\
\hline Yes & $159(13.6)$ & $\begin{array}{l}0.71(0.19- \\
2.66)\end{array}$ & $\begin{array}{l}0.49(0.17- \\
1.40)\end{array}$ & $\begin{array}{l}0.12(0.02- \\
0.78)^{*}\end{array}$ & $\begin{array}{l}1.40(0.66- \\
2.95)\end{array}$ & $\begin{array}{l}2.43(0.94- \\
6.32)\end{array}$ & $0.85(0.34-2.15)$ \\
\hline No & $1007(86.4)$ & - & - & & - & - & - \\
\hline \multicolumn{8}{|c|}{ Health condition—family } \\
\hline Yes & $281(24.1)$ & $\begin{array}{l}0.94(0.36- \\
2.44)\end{array}$ & $\begin{array}{l}1.89(0.92- \\
3.90)\end{array}$ & $\begin{array}{l}2.37(0.62- \\
9.00)\end{array}$ & $\begin{array}{l}0.48(0.25- \\
0.91)^{*}\end{array}$ & $\begin{array}{l}0.82(0.36- \\
1.90)\end{array}$ & $2.18(1.09-4.33) *$ \\
\hline No & $885(75.9)$ & - & - & - & - & - & - \\
\hline \multicolumn{8}{|c|}{ C19 infection-self } \\
\hline Yes & $104(8.9)$ & $\begin{array}{l}1.48(0.50- \\
4.38)\end{array}$ & $\begin{array}{l}0.86(0.33- \\
2.28)\end{array}$ & $\begin{array}{l}0.54(0.10- \\
2.97)\end{array}$ & $\begin{array}{l}1.01(0.46- \\
2.19)\end{array}$ & $\begin{array}{l}0.66(0.17- \\
2.54)\end{array}$ & $0.81(0.31-2.09)$ \\
\hline No & $1062(91.1)$ & - & - & - & - & - & - \\
\hline \multicolumn{8}{|c|}{ C19 infection-family member } \\
\hline Yes & $113(9.7)$ & $\begin{array}{l}2.00(0.64- \\
6.27)\end{array}$ & $\begin{array}{l}1.45(0.57- \\
3.68)\end{array}$ & $\begin{array}{l}0.55(0.09- \\
3.57)\end{array}$ & $\begin{array}{l}1.58(0.71- \\
3.53)\end{array}$ & $\begin{array}{l}1.18(0.41- \\
3.39)\end{array}$ & $1.07(0.39-2.92)$ \\
\hline No & $1053(90.3)$ & - & - & - & - & - & - \\
\hline \multicolumn{8}{|c|}{ C19 death—someone close } \\
\hline Yes/uncertain & $70(6.0)$ & $\begin{array}{l}1.99(0.43- \\
9.21)\end{array}$ & $\begin{array}{l}0.97(0.27- \\
3.51)\end{array}$ & $\begin{array}{l}2.72(0.36- \\
20.69)\end{array}$ & $\begin{array}{l}1.30(0.47- \\
3.59)\end{array}$ & $\begin{array}{l}1.21(0.29- \\
5.04)\end{array}$ & $1.65(0.54-5.07)$ \\
\hline No & $1096(94.0)$ & - & - & - & - & - & - \\
\hline \multicolumn{8}{|l|}{ C19 anxiety } \\
\hline High & $359(30.8)$ & $\begin{array}{l}1.55(0.57- \\
4.25)\end{array}$ & $\begin{array}{l}0.62(0.27- \\
1.43)\end{array}$ & $\begin{array}{l}2.58(0.49- \\
13.55)\end{array}$ & $\begin{array}{l}1.13(0.62- \\
2.08)\end{array}$ & $\begin{array}{l}1.74(0.74- \\
4.10)\end{array}$ & $2.42(0.99-5.96)$ \\
\hline Moderate & $475(40.8)$ & $\begin{array}{l}1.68(0.65- \\
4.37)\end{array}$ & $\begin{array}{l}1.10(0.53- \\
2.25)\end{array}$ & $\begin{array}{l}2.24(0.46- \\
10.78)\end{array}$ & $\begin{array}{l}1.04(0.60- \\
1.80)\end{array}$ & $\begin{array}{l}0.82(0.36- \\
1.87)\end{array}$ & $1.97(0.83-4.68)$ \\
\hline Low & $331(28.4)$ & - & - & - & - & - & - \\
\hline \multicolumn{8}{|l|}{ Keyworker } \\
\hline No & $854(73.2)$ & $\begin{array}{l}1.40(0.58- \\
3.34)\end{array}$ & $\begin{array}{l}1.73(0.81- \\
3.68)\end{array}$ & $\begin{array}{l}0.21(0.06- \\
0.80)^{*}\end{array}$ & $\begin{array}{l}1.05(0.60- \\
1.83)\end{array}$ & $\begin{array}{l}2.38(1.06- \\
5.34)^{*}\end{array}$ & $1.13(0.53-2.39)$ \\
\hline Yes & $296(25.4)$ & - & - & - & - & - & - \\
\hline \multicolumn{8}{|c|}{ Living in local lockdown } \\
\hline Yes & $79(6.8)$ & $\begin{array}{l}0.68(0.13- \\
3.53)\end{array}$ & $\begin{array}{l}1.67(0.55- \\
5.05)\end{array}$ & $\begin{array}{l}4.86(1.09- \\
21.60)^{*}\end{array}$ & $\begin{array}{l}0.09(0.01- \\
0.61)^{*}\end{array}$ & $\begin{array}{l}1.05(0.28- \\
4.04)\end{array}$ & $3.19(1.16-8.75) *$ \\
\hline No & $1087(93.2)$ & - & - & - & - & - & - \\
\hline \multicolumn{8}{|c|}{ Depression caseness } \\
\hline Yes & $257(22.1)$ & $\begin{array}{l}0.86(0.20- \\
3.66)\end{array}$ & $\begin{array}{l}2.07(0.83- \\
5.18)\end{array}$ & $\begin{array}{l}1.61(0.40- \\
6.50)\end{array}$ & $\begin{array}{l}2.20(0.95- \\
5.13)\end{array}$ & $\begin{array}{l}0.89(0.30- \\
2.67)\end{array}$ & $1.52(0.67-3.45)$ \\
\hline No & 909 (77.9) & - & - & - & - & - & - \\
\hline \multicolumn{8}{|l|}{ GAD caseness } \\
\hline Yes & 205 (17.6) & $\begin{array}{l}2.03(0.50- \\
8.20)\end{array}$ & $\begin{array}{l}2.06(0.81- \\
5.24)\end{array}$ & $\begin{array}{l}2.07(0.54- \\
8.00)\end{array}$ & $\begin{array}{l}0.84(0.32- \\
2.15)\end{array}$ & $\begin{array}{l}1.32(0.40- \\
4.39)\end{array}$ & $1.22(0.51-2.92)$ \\
\hline No & $961(82.4)$ & - & - & - & - & - & - \\
\hline \multicolumn{8}{|c|}{ C-19 PTSD caseness } \\
\hline Yes & $185(15.8)$ & $\begin{array}{l}0.94(0.29- \\
3.06)\end{array}$ & $\begin{array}{l}1.98(0.89- \\
4.41)\end{array}$ & $\begin{array}{c}5.88(1.70- \\
20.41)^{* *}\end{array}$ & $\begin{array}{l}1.85(0.84- \\
4.07)\end{array}$ & $\begin{array}{l}0.92(0.29- \\
2.91)\end{array}$ & $2.20(1.02-4.74) *$ \\
\hline
\end{tabular}


Table 4 (continued)

\begin{tabular}{|c|c|c|c|c|c|c|c|}
\hline & \multirow{2}{*}{$\begin{array}{l}N(\%) / \text { means } \\
\text { (range) }\end{array}$} & \multicolumn{6}{|l|}{ OR $(95 \%$ CI $)$} \\
\hline & & $\begin{array}{l}\text { Class } 1(3.3 \%) \\
\text { Better overall }\end{array}$ & $\begin{array}{l}\text { Class } 2(6.0 \%) \\
\text { Worse except } \\
\text { partner }\end{array}$ & $\begin{array}{l}\text { Class } 3(2.5 \%) \\
\text { Worse overall }\end{array}$ & $\begin{array}{l}\text { Class } 4(9.5 \%) \\
\text { Better relation- } \\
\text { ships }\end{array}$ & $\begin{array}{l}\text { Class } 5(4.3 \%) \\
\text { Better except } \\
\text { partner }\end{array}$ & $\begin{array}{l}\text { Class } 7(6.5 \%) \\
\text { Worse partner } \\
\text { only }\end{array}$ \\
\hline No & $981(84.2)$ & - & - & - & - & - & - \\
\hline \multicolumn{8}{|c|}{ C-19 suicidal ideation } \\
\hline Yes & $160(15.2)$ & $\begin{array}{l}1.31(0.45- \\
3.88)\end{array}$ & $\begin{array}{l}0.89(0.40- \\
1.94)\end{array}$ & $\begin{array}{l}4.24(1.22- \\
14.71)^{*}\end{array}$ & $\begin{array}{l}0.92(0.40- \\
2.11)\end{array}$ & $\begin{array}{l}1.24(0.50- \\
3.08)\end{array}$ & $\begin{array}{l}3.26(1.55- \\
6.85)^{* *}\end{array}$ \\
\hline No & $890(84.8)$ & - & - & - & - & - & - \\
\hline \multicolumn{8}{|c|}{ Psychological variables } \\
\hline Loneliness & $5.00(3-9)$ & $\begin{array}{l}1.04(0.80- \\
1.34)\end{array}$ & $\begin{array}{l}1.22(1.01- \\
1.48)^{*}\end{array}$ & $\begin{array}{l}1.05(0.72- \\
1.53)\end{array}$ & $\begin{array}{l}1.08(0.90- \\
1.29)\end{array}$ & $\begin{array}{l}1.21(0.98- \\
1.50)\end{array}$ & $\begin{array}{c}1.49(1.21- \\
1.83)^{* * *}\end{array}$ \\
\hline Hopefulness & $6.42(2-10)$ & $\begin{array}{c}1.55(1.19- \\
2.01)^{* * *}\end{array}$ & $\begin{array}{l}0.92(0.77- \\
1.09)\end{array}$ & $\begin{array}{l}0.90(0.64- \\
1.28)\end{array}$ & $\begin{array}{l}1.06(0.91- \\
1.25)\end{array}$ & $\begin{array}{l}1.27(1.04- \\
1.55)^{*}\end{array}$ & $1.17(0.96-1.41)$ \\
\hline Happiness & $4.37(1-7)$ & $\begin{array}{l}1.51(0.94- \\
2.43)\end{array}$ & $\begin{array}{c}1.21(0.87- \\
1.70)\end{array}$ & $\begin{array}{l}0.65(0.33- \\
1.27)\end{array}$ & $\begin{array}{c}1.43(1.08- \\
1.89)^{*}\end{array}$ & $\begin{array}{c}1.16(0.82- \\
1.63)\end{array}$ & $0.82(0.59-1.15)$ \\
\hline Social support & $26.27(8-40)$ & $\begin{array}{l}1.01(0.97- \\
1.05)\end{array}$ & $\begin{array}{l}0.98(0.95- \\
1.01)\end{array}$ & $\begin{array}{l}0.98(0.92- \\
1.04)\end{array}$ & $\begin{array}{l}1.03(1.01- \\
1.06)^{*}\end{array}$ & $\begin{array}{l}1.01(0.98- \\
1.05)\end{array}$ & $0.98(0.95-1.01)$ \\
\hline Resilience & $19.68(6-30)$ & $\begin{array}{l}0.91(0.82- \\
1.01)\end{array}$ & $\begin{array}{l}0.99(0.91- \\
1.08)\end{array}$ & $\begin{array}{l}1.12(0.95- \\
1.33)\end{array}$ & $\begin{array}{l}1.01(0.95- \\
1.08)\end{array}$ & $\begin{array}{l}1.04(0.96- \\
1.13)\end{array}$ & $1.04(0.96-1.13)$ \\
\hline Death anxiety & $43.19(17-85)$ & $\begin{array}{l}1.05(1.01- \\
1.08)^{*}\end{array}$ & $\begin{array}{l}1.00(0.97- \\
1.02)\end{array}$ & $\begin{array}{l}1.07(1.02- \\
1.13)^{* *}\end{array}$ & $\begin{array}{l}1.00(0.99- \\
1.02)\end{array}$ & $\begin{array}{l}0.99(0.96- \\
1.01)\end{array}$ & $1.01(0.99-1.04)$ \\
\hline $\begin{array}{l}\text { Intolerance of } \\
\text { uncertainty }\end{array}$ & $35.32(12-60)$ & $\begin{array}{l}0.98(0.93- \\
1.04)\end{array}$ & $\begin{array}{l}1.02(0.98- \\
1.06)\end{array}$ & $\begin{array}{l}0.97(0.90- \\
1.05)\end{array}$ & $\begin{array}{l}1.02(0.98- \\
1.05)\end{array}$ & $\begin{array}{l}1.04(1.00- \\
1.09)\end{array}$ & $0.98(0.94-1.03)$ \\
\hline
\end{tabular}

Class 6 (no difference) is reference class. Significant ORs in bold

$* p<0.05$

$* * p<0.01$

$* * * p<0.001$

UK population whose lifestyle had worsened in relation to at least one dimension of pandemic-related lifestyle change.

Class 3 exhibited the most extreme deterioration in lifestyle change and this was evident across all dimensions. Compared to Class 3, Class 2 was characterised by a similar but less severe pattern of negative change across all dimensions except the partner relations dimension, where little change was identified. Conversely, Class 7 exhibited relatively little change across all lifestyle dimensions, except partner relations, where the level of deterioration was similar to that identified in Class 3. Overall, therefore, class composition suggested that, when lifestyle quality changed during the pandemic, it centred around either positive/negative changes (i) across all aspects of lifestyle quality, (ii) across all areas except partner relationships and (iii) to partner relationships only (or in the case of Class 4, positive changes to the quality of relationships generally).

Of the negative lifestyle change classes, compared to the no-change baseline majority (i.e. Class 6), only Classes 3 and 7 were more likely to experience mental health problems. Members of both classes were more likely to meet caseness for COVID-19 traumatic stress and report suicidal ideation. Members of both classes were also more likely to be in a relationship, and live in an area that was under local lockdown. Classes 3 and 7 were, however, distinct from each other in relation to other covariates. Membership of Class 3 (deterioration across all dimensions) was uniquely predicted by city living, being white, an absence of an underlying health condition, and being a keyworker, while membership of Class 7 (deterioration in partner relations only) was predicted by a medium income level, children in the home, living in a two-bedroom property, lost income due to the pandemic, the presence of an underlying health condition, and higher levels of loneliness. Somewhat surprisingly, while Class 2 experienced deterioration in four of the five lifestyle dimensions, it was not at greater risk of mental ill health and was predicted only by economic activity status and loneliness.

Class 3 clearly demonstrates that some members of the population are experiencing extreme difficulties during the pandemic and that multiple aspects of their lives are being affected. Their city living and frontline worker status are likely to impact their lifestyles and contribute to fears of contagion, infection, and illness that commonly arise from higher rates of transmission in more populated areas [51], and greater exposure in frontline working environments [52]. 
Class 7 suggests that compromised partner relations may be a particularly meaningful aspect of lifestyle change during the pandemic that, in itself, signals other important difficulties in household circumstances such as having dependent children in the home, living in a smaller house, higher levels of loneliness, having a family member with a chronic health condition (who may or may not live in the home) and having lost income, all factors known to compromise relationships and well-being pre-pandemic [53-57].

Compromised partner relations may also, however, be consequential to other pandemic related factors. A number of COVID-19-related studies have begun to explore this. Using data from an online nationally representative probability survey of 1,010 American adults in April 2020, for example, Luetke et al. [13] found that $34 \%$ of respondents in a relationship reported some degree of conflict with their romantic partners due to the spread of COVID-19 and its related restrictions. In addition, they reported that individuals who experienced frequent coronavirus-related conflict with their partner were significantly more likely to report decreased frequency of intimate and sexual behaviours compared to those not experiencing any such conflict, exhibiting a dose-response trend among partnered sexual behaviours. Pietromonaco et al. [30] suggest that facing COVID-19-related external stress is likely to increase harmful dyadic processes (e.g. hostility, withdrawal, less responsive support), which may undermine couples' relationship quality. Moreover, these harmful effects are likely to be exacerbated by the broader pre-existing context in which couples' relationships are situated (e.g. social class, minority status, age), and their individual vulnerabilities (e.g. attachment insecurity, depression). Prime, Wade and Browne [58] state that the COVID-19 pandemic poses an acute threat to the well-being of families due to challenges related to social disruption such as financial insecurity, caregiving burden, and confinementrelated stress (e.g. crowding, changes to routine). According to these authors, the consequences of these difficulties are likely to be longstanding, in part because of the ways in which contextual risk permeates the structures and processes of family systems.

Finally, a growing number of studies have reported increases in domestic and intimate partner violence during the pandemic [59-61]. For example, a $60 \%$ increase in emergency calls from women subjected to violence by their intimate partner has been reported in the World Health Organization Europe member states. Comparing April 2020 with the same period last year, WHO reported that online inquiries to violence prevention support hotlines had also increased as much as fivefold [14]. Overall therefore, relationship complications (that may have existed before and/ or been caused/compounded by the pandemic), alongside negative changes in other lifestyle dimensions in some cases, seem to constitute the more severe pandemic-related lifestyle quality change due to their association with poor mental health (COVID-19 PTSD and recent suicidal ideation) and are therefore an important marker for investigation.

The current study's strengths include its sample size and use of weighting procedures to ensure the sample was nationally representative of the UK population across a number of sociodemographic indicators. Additionally, the sophisticated analytic strategy employed allowed for a better understanding of the complex ways in which the pandemic has affected people's lives. There are, however, several limitations of the study to consider. Firstly, the crosssectional design limits interpretations relating to causality. Secondly, the lifestyle indicator items asked participants to retrospectively reflect on their lives now compared to before the pandemic, and thus may be susceptible to recall bias. The current study used data from Wave 3 of the C19PRC Study, which was gathered during July 2020. At this time, the UK was past the peak of its first wave of coronavirus and the daily number of cases and deaths had reduced. As a result, lockdown measures were eased, and some individuals were able to engage with more 'normal' routines. Future research should consider pandemic-related lifestyle change in the light of further waves of coronavirus cases and the reinstatement of lockdown periods. Third, quota sampling was used to recruit participants via non-probability, opt-in online survey panels which excluded participants who did not have access to the Internet and those who could not read or write in English. Relatedly, this sampling strategy may have been susceptible to a number of biases (sampling bias, non-response bias, demand characteristics bias, question order bias, personality biases, psychometric biases) that have been shown to undermine confidence in online survey research findings [62-64]. Fourth, the low number of cases in some of the latent classes in the best fitting LPA model may have impeded the detection of some effects. Finally, although framed around the pandemic, we do not know with certainty whether these changes were as a result of the pandemic, either directly or indirectly.

Supplementary Information The online version contains supplementary material available at https://doi.org/10.1007/s00127-021-02210-w.

Author contributions Conceptualisation/design of the work: JM, PH, SB; acquisition of data: all authors; analysis of data: SB, JM; drafted the work: SB, JM; substantively revised the work: PH, OMB, MS, TKH, KB, JGM, LL, APM, LM, RM, TVAS, FV, RPB.

Funding The initial stages of this project were supported by start-up funds from the University of Sheffield (Department of Psychology, the Sheffield Methods Institute and the Higher Education Innovation Fund via an Impact Acceleration grant administered by the university) and by the Faculty of Life and Health Sciences at Ulster University. The research was subsequently supported by the ESRC (grant ref. ES/ V004379/1): 'A longitudinal mixed-methods population study of the UK during the COVID-19 pandemic: Psychological and social adjustment to a global threat'. 
Availability of data and materials Survey data from the C19PRC Study UK Waves 1-3 can be found at https://osf.io/v2zur/files/.

\section{Declarations}

Conflict of interest On behalf of all authors, the corresponding author states that there is no conflict of interest.

Ethical approval Ethical approval for the project was provided by the University of Sheffield (Reference number 033759).

Consent to participate Informed consent was obtained from all individual participants included in the study.

Consent for publication All participants consented for their non-identifiable information to be used in reports and publications.

Open Access This article is licensed under a Creative Commons Attribution 4.0 International License, which permits use, sharing, adaptation, distribution and reproduction in any medium or format, as long as you give appropriate credit to the original author(s) and the source, provide a link to the Creative Commons licence, and indicate if changes were made. The images or other third party material in this article are included in the article's Creative Commons licence, unless indicated otherwise in a credit line to the material. If material is not included in the article's Creative Commons licence and your intended use is not permitted by statutory regulation or exceeds the permitted use, you will need to obtain permission directly from the copyright holder. To view a copy of this licence, visit http://creativecommons.org/licenses/by/4.0/.

\section{References}

1. Balanzá-Martínez V, Atienza-Carbonell B, Kapczinski F, De Boni RB (2020) Lifestyle behaviours during the COVID-19-time to connect. Acta Psychiatr Scand 141:399-400. https://doi.org/10. 1111/acps. 13177

2. Ferguson N, Laydon D, Nedjati-Gilani G et al (2020) Report 9: impact of non-pharmaceutical interventions (NPIs) to reduce COVID19 mortality and healthcare demand. Imperial College London, London. https://doi.org/10.25561/77482

3. Holmes EA, O'Connor RC, Perry VH et al (2020) Multidisciplinary research priorities for the COVID-19 pandemic: a call for action for mental health science. Lancet Psychiatry 7:547-560. https://doi.org/10.1016/S2215-0366(20)30168-1

4. Moreno C, Wykes T, Galderisi S et al (2020) How mental health care should change as a consequence of the COVID-19 pandemic. Lancet Psychiatry 7:813-824. https://doi.org/10.1016/S22150366(20)30307-2

5. World Health Organization (2020) Mental health and psychosocial considerations during the COVID-19 outbreak. World Health Organization. Available at https://www.who.int/docs/defaultsource/coronaviruse/mental-health-considerations.pdf. Accessed 14 Mar 2021

6. Prati G, Mancini A (2021) The psychological impact of COVID19 pandemic lockdowns: a review and meta-analysis of longitudinal studies and natural experiments. Psychol Med 51:201-211. https://doi.org/10.1017/S0033291721000015

7. Ahrens KF, Neumann RJ, Kollmann B et al (2021) Differential impact of COVID-related lockdown on mental health in Germany. World Psychiatry 20:140-141. https://doi.org/10.1002/wps.20830
8. Shevlin M, Butter S, McBride O et al (2021) Refuting the myth of a 'tsunami' of mental ill-health in populations affected by COVID-19: evidence that response to the pandemic is heterogenous, not homogeneous. Psychol Med. https://doi.org/10.1017/ S0033291721001665

9. Górnicka M, Drywień ME, Zielinska MA, Hamułka J (2020) Dietary and lifestyle changes during COVID-19 and the subsequent lockdowns among Polish adults: a cross-sectional online survey PLifeCOVID-19 study. Nutrients 12:2324. https://doi.org/ 10.3390/nu12082324

10. Meyer J, McDowell C, Lansing J et al (2020) Changes in physical activity and sedentary behavior in response to COVID-19 and their associations with mental health in 3052 US adults. Int J Environ Res Public Health 17:6469. https://doi.org/10.33774/ coe-2020-h0b8g

11. Robinson E, Gillespie S, Jones A (2020) Weight-related lifestyle behaviours and the COVID-19 crisis: an online survey study of UK adults during social lockdown. Obes Sci Pract 6:735-740. https://doi.org/10.1002/osp4.442

12. Ammar A, Chtourou H, Boukhris O et al (2020) COVID-19 home confinement negatively impacts social participation and life satisfaction: a worldwide multicenter study. Int J Environ Res Public Health 17:6237. https://doi.org/10.3390/ijerph17176237

13. Luetke M, Hensel D, Herbenick D, Rosenberg M (2020) Romantic relationship conflict due to the COVID-19 pandemic and changes in intimate and sexual behaviors in a nationally representative sample of American adults. J Sex Marital Ther 46:747-762. https://doi.org/10.1080/0092623X.2020.1810185

14. Mahase E (2020) Covid-19: EU states report $60 \%$ rise in emergency calls about domestic violence. Br Med J 369:m1872. https:// doi.org/10.1136/bmj.m1872

15. Möhring K, Naumann E, Reifenscheid M et al (2021) The COVID-19 pandemic and subjective well-being: longitudinal evidence on satisfaction with work and family. Eur Soc 23:S601S617. https://doi.org/10.1080/14616696.2020.1833066

16. Schmid L, Wörn J, Hank K, Sawatzki B, Walper S (2021) Changes in employment and relationship satisfaction in times of the COVID-19 pandemic: evidence from the German family Panel. Eur Soc 23:S743-S758. https://doi.org/10.1080/14616696.2020. 1836385

17. Bell DN, Blanchflower DG (2020) US and UK labour markets before and during the Covid-19 crash. Natl Inst Econ Rev 252:R52-R69. https://doi.org/10.1017/nie.2020.14

18. International Labour Organization (2020) COVID-19 and the world of work. Second edition: Updated estimates and analysis. International Labour Organization. Available at https://www.ilo. org/wcmsp5/groups/public/---dgreports/---dcomm/documents/ briefingnote/wcms_740877.pdf. Accessed 14 Mar 2021

19. Wielgoszewska B, Green F, Goodman A (2020) Finances and employment during lockdown: Initial findings from the COVID19 Survey in Five National Longitudinal Studies. London; UCL Centre for Longitudinal Studies. Available at https://cls.ucl.ac.uk/ wp-content/uploads/2017/02/Finances-and-employment-duringlockdown-\%E2\%80\%93-initial-findings-from-COVID-19-survey. pdf. Accessed 14 Mar 2021

20. Feng Z, Savani K (2020) Covid-19 created a gender gap in perceived work productivity and job satisfaction: implications for dual-career parents working from home. Gend Manag 35:719736. https://doi.org/10.1108/GM-07-2020-0202

21. Shanafelt T, Ripp J, Trockel M (2020) Understanding and addressing sources of anxiety among health care professionals during the COVID-19 pandemic. JAMA 323:2133-2134. https://doi.org/10. 1001/jama.2020.5893

22. Zhang SX, Wang Y, Rauch A, Wei F (2020) Unprecedented disruption of lives and work: Health, distress and life satisfaction of working adults in China one month into the COVID-19 outbreak. 
Psychiatry Res 288:112958. https://doi.org/10.1016/j.psychres. 2020.112958

23. Ammar A, Mueller P, Trabelsi K et al (2020) Psychological consequences of COVID-19 home confinement: The ECLB-COVID19 multicenter study. PLoS ONE 15:e0240204. https://doi.org/10. 1371/journal.pone.0240204

24. Cox N, Ganong P, Noel P et al (2020) Initial impacts of the pandemic on consumer behavior: Evidence from linked income, spending, and savings data. University of Chicago; Becker Friedman Institute for Economics, Chicago. https://doi.org/10.2139/ ssrn. 3633008

25. Reichelt M, Makovi K, Sargsyan A (2021) The impact of COVID19 on gender inequality in the labor market and gender-role attitudes. Eur Soc 23:S228-S245. https://doi.org/10.1080/14616696. 2020.1823010

26. Hipp L, Bünning M (2021) Parenthood as a driver of increased gender inequality during COVID-19? Exploratory evidence from Germany. Eur Soc 23:S658-S673. https://doi.org/10.1080/14616 696.2020.1833229

27. Petts RJ, Carlson DL, Pepin JR (2021) A gendered pandemic: childcare, homeschooling, and parents' employment during COVID-19. Gend Work Organ 28:515-534. https://doi.org/10. 1111/gwao.12614

28. Amerio A, Brambilla A, Morganti A et al (2020) Covid-19 lockdown: housing built environment's effects on mental health. Int $\mathbf{J}$ Environ Res Public Health 17:5973. https://doi.org/10.3390/ijerp h17165973

29. Balzarini RN, Muise A, Zoppolat G et al (2020) Love in the time of Covid: Perceived partner responsiveness buffers people from lower relationship quality associated with Covid-related stressors. PsyArXiv preprint. https://doi.org/10.31234/osf.io/e3fh4

30. Pietromonaco PR, Overall NC (2021) Applying relationship science to evaluate how the COVID-19 pandemic may impact couples' relationships. Am Psychol 76:438-450. https://doi.org/10. 1037/amp0000714

31. McBride O, Butter S, Murphy J et al (2021) Context, design and conduct of the longitudinal COVID-19 Psychological Research Consortium (C19PRC) Study-Wave 3. Int J Methods Psychiatr Res 30:e1880. https://doi.org/10.1002/mpr.1880

32. McBride O, Murphy J, Shevlin M et al (2021) Monitoring the psychological, social, and economic impact of the COVID19 pandemic in the population: context, design and conduct of the longitudinal COVID-19 psychological research consortium (C19PRC) study. Int J Methods Psychiatr Res 30:e1861. https:// doi.org/10.1002/mpr.1861

33. Hughes ME, Waite LJ, Hawkley LC, Cacioppo JT (2004) A short scale for measuring loneliness in large surveys: results from two population-based studies. Res Aging 26:655-672

34. Lyubomirsky S, Lepper HS (1999) A measure of subjective happiness: preliminary reliability and construct validation. Soc Indic Res 46:137-155

35. Fraser L, Burnell M, Salter LC et al (2014) Identifying hopelessness in population research: a validation study of two brief measures of hopelessness. BMJ Open 4:e005093. https://doi.org/ 10.1136/bmjopen-2014-005093

36. Moser A, Stuck AE, Silliman RA, Ganz PA, Clough-Gorr KM (2012) The eight-item modified Medical outcomes study social support survey: psychometric evaluation showed excellent performance. J Clin Epidemiol 65:1107-1116

37. Smith BW, Dalen J, Wiggins K et al (2008) The brief resilience scale: assessing the ability to bounce back. Int J Behav Med 15:194-200

38. Tomás-Sábado J, Gómez-Benito J, Limonero J (2005) The death anxiety inventory: a revision. Psychol Rep 97:793-796. https:// doi.org/10.2466/pr0.97.3.793-796
39. Buhr K, Dugas MJ (2002) The intolerance of uncertainty scale: psychometric properties of the English version. Behav Res Ther 40:931-945

40. Kroenke K, Spitzer RL, Williams JB (2001) The PHQ-9: Validity of a brief depression severity measure. J Gen Intern Med 16:606613. https://doi.org/10.1046/j.1525-1497.2001.016009606.x

41. Spitzer RL, Kroenke K, Williams JB, Löwe B (2006) A brief measure for assessing generalized anxiety disorder: the GAD-7. Arch Intern Med 166:1092-1097. https://doi.org/10.1001/archi nte.166.10.1092

42. Cloitre M, Shevlin M, Brewin CR et al (2018) The International Trauma Questionnaire: development of a self-report measure of ICD-11 PTSD and complex PTSD. Acta Psychiatr Scand 138:536-546. https://doi.org/10.1111/acps.12956

43. Akaike H (1987) Factor analysis and AIC. Psychometrika 52:317332. https://doi.org/10.1007/BF02294359

44. Schwarz G (1978) Estimating the dimension of a model. Ann Stat 6:461-464

45. Sclove SL (1987) Application of model-selection criteria to some problems in multivariate analysis. Psychometrika 52:333343. https://doi.org/10.1007/BF02294360

46. Nylund KL, Asparouhov T, Muthén BO (2007) Deciding on the number of classes in latent class analysis and growth mixture modeling: a Monte carlo simulation study. Struct Equ Model 14:535-569. https://doi.org/10.1080/10705510701575396

47. Lo Y, Mendell NR, Rubin DB (2001) Testing the number of components in a normal mixture. Biometrika 88:767-778. https://doi.org/10.1093/biomet/88.3.767

48. Yuan K-H, Bentler PM (2000) Three likelihood-based methods for mean and covariance structure analysis with nonnormal missing data. Sociol Methodol 30:165-200. https://doi.org/10. 1111/0081-1750.00078

49. Muthén LK, Muthén B (2017) Mplus user's guide: statistical analysis with latent variables, user's guide. Muthén \& Muthén, Los Angeles

50. Stevens JP (2012) Applied multivariate statistics for the social sciences. Routledge, Milton Park

51. Capolongo S, Rebecchi A, Buffoli M et al (2020) COVID-19 and cities: From urban health strategies to the pandemic challenge. A decalogue of public health opportunities. Acta Bio Medica Atenei Parmensis 91:13. https://doi.org/10.23750/abm. v91i2.9515

52. Dennerlein JT, Burke L, Sabbath EL et al (2020) An integrative total worker health framework for keeping workers safe and healthy during the COVID-19 pandemic. Hum Factors 62:689696. https://doi.org/10.1177/0018720820932699

53. Beutel ME, Klein EM, Brähler E et al (2017) Loneliness in the general population: prevalence, determinants and relations to mental health. BMC Psychiatry 17:97. https://doi.org/10.1186/ s12888-017-1262-x

54. Evans GW, Wells NM, Moch A (2003) Housing and mental health: a review of the evidence and a methodological and conceptual critique. J Soc Issues 59:475-500. https://doi.org/10.1111/ 1540-4560.00074

55. Kenny P, King MT, Hall J (2014) The physical functioning and mental health of informal carers: evidence of care-giving impacts from an Australian population-based cohort. Health Soc Care Commun 22:646-659. https://doi.org/10.1111/hsc.12136

56. McLanahan S, Adams J (1987) Parenthood and psychological well-being. Ann Rev Sociol 13:237-257. https://doi.org/10.1146/ annurev.so.13.080187.001321

57. Sculpher MJ, O'Brien BJ (2000) Income effects of reduced health and health effects of reduced income: implications for health-state valuation. Med Decis Making 20:207-215. https://doi.org/10. 1177/0272989X0002000206 
58. Prime H, Wade M, Browne DT (2020) Risk and resilience in family well-being during the COVID-19 pandemic. Am Psychol 75:631-643. https://doi.org/10.1037/amp0000660

59. Boxall H, Morgan A, Brown R (2020) The prevalence of domestic violence among women during the COVID-19 pandemic. Australas Policing 12:38-46

60. Campbell AM (2020) An increasing risk of family violence during the Covid-19 pandemic: strengthening community collaborations to save lives. Forensic Sci Int 2:100089. https://doi.org/10.1016/j. fsir.2020.100089

61. Ertan D, El-Hage W, Thierrée S, Javelot H, Hingray C (2020) COVID-19: Urgency for distancing from domestic violence. Eur J Psychotraumatol 11:1800245. https://doi.org/10.1080/20008198. 2020.1800245
62. Tellis GJ, Chandrasekaran D (2010) Extent and impact of response biases in cross-national survey research. Int J Res Mark 27:329_ 341. https://doi.org/10.1016/j.ijresmar.2010.08.003

63. Valentino NA, Zhirkov K, Hillygus DS, Guay B (2020) The consequences of personality biases in online panels for measuring public opinion. Public Opin Q 84:446-468. https://doi.org/10. 1093/poq/nfaa026

64. McCoy S, Marks PV, Carr CL, Mbarika V (2004) Electronic versus paper surveys: Analysis of potential psychometric biases. Proceedings of the 37th Annual Hawaii International Conference on System Sciences, 2004: IEEE 